\title{
Assessment of sublethal pollutant impact on flounders in an industrialised estuary using hepatic biochemical indices
}

\author{
N. Sulaiman ${ }^{1}$, S. George ${ }^{1, *}$, M. D. Burke ${ }^{2}$ \\ ${ }^{1}$ NERC Unit of Aquatic Biochemistry, Department of Molecular and Biological Sciences, University of Stirling, FK9 4LA, \\ Scotland, United Kingdom \\ ${ }^{2}$ Department of Pharmacology, University of Aberdeen, Scotland, United Kingdom
}

\begin{abstract}
Flounder Platichthys flesus from a pollution gradient in the Forth estuary, Scotland, were analysed for specific cytochrome P-450 and metal-binding protein induction as an indication of sublethal impact of organic xenobiotics and Group IIB metals respectively. Hepatic ethoxyresorufin $O$ deethylase (EROD) activity in fish from a reference site was around $9 \mathrm{nmol}(\mathrm{g} l i v e r)^{-1} \mathrm{~min}^{-1}$ and increased up to 9 -fold in the area near discharges from a major petrochemical complex. Hepatic metallothionein (MT) content rose from $20 \mu \mathrm{g}$ (g liver) $^{-1}$ at the uppermost site by ca 19 -fold near the petrochemical complex. The study further demonstrates the validity of biochemical measurements for the assessment of pollutant impact in an estuarine environment.
\end{abstract}

\section{INTRODUCTION}

Following the recommendations of the GESAMP report (1980) there has been increased effort over the past decade in the application and validation of biochemical and physiological methods for the indication of sublethal environmental pollutant effects. These methods might serve as a compliment to the statutory requirements for chemical monitoring, as well as providing information on the biological availability of pollutants. A number of workshops have been convened by GEEP and ICES/IOC to evaluate current techniques on a correlative basis (e.g. Bayne et al. 1988). In the present study we have utilised 2 primary biochemical responses to assess pollutant impact. The cytochromes P-450 are a family of haemoproteins catalysing the initial phase of biotransformation of many organic compounds including steroid hormones, drugs, carcinogens and pollutants (Boobis et al. 1985). Synthesis of several of the isoforms of cytochrome P-450 is regulated by these compounds, and levels of one such cytochrome P450 , cytochrome P-450 1A1, which catalyses ethoxyresorufin $O$-deethylation (EROD) and benzo(a)pyrene hydroxylation (Heilmann et al. 1988), have been shown

\footnotetext{
- Addressee for correspondence
}

to be specifically induced in fish liver by co-planar polychlorinated biphenyl (PCB) congeners or polyaromatic hydrocarbons (PAH) (reviewed e.g. by Kleinow et al. 1987, Stegeman \& Kloepper-Sams 1987). Measurement of EROD activity levels has thus been suggested as an indicator of environmental exposure to such inducèrs (e.g. Payne et al. 1987) and was used in a GEEP workshop to assess pollutant impact in flounders collected along a pollution gradient in the Langesundfjord, Norway (Addison \& Edwards 1988, Stegeman et al. 1988). Metallothionein (MT), which appears to be ubiquitous in vertebrates, is a low molecular weight cytosolic metal-binding protein whose function is mainly in binding Group IIB metals (Kagi \& Kojima 1987). Its synthesis is readily induced by copper, cadmium and zinc both in mammals (reviewed by Hamer 1987) and in fish (reviewed by George 1990). Use of MT levels as an index of environmental metal pollution has been proposed by Hamilton \& Mehrle (1986) and its use in the marine environment has been discussed recently (George 1990). In the Langesundfjord study, flounder MT levels were also measured (Overnell \& Abdullah 1988).

In the present study measurements of EROD activities and MT levels have been employed as primary response indices to evaluate biological effects of 
pollutants on flounders collected from sites along the Forth estuary, Eastern Scotland, which receives discharges of municipal sewage and industrial effluents from a distillery, metal works and a major petrochemical production and refinery complex which also discharges North Sea oil production water.

\section{MATERIALS AND METHODS}

Sexually immature flounders Platichthys flesus were sampled in September from the River Forth and its estuary (Fig. 1) by electrofishing at Cornton (near Stirling) the upper site, moored commercial stake fishing boats at the middle stations at Alloa and Kincardine and by Agassiz trawl at the lower stations at Longannet and Port Edgar. Fish from reference areas on the Firth of Clyde estuary (western Scotland) at Millport were caught by trawling whereas those from the Ythan estuary (northeast Scotland) were caught by hand seine net. Fish were transported to the laboratory live. After recording lengths and weights the fish were killed by a blow to the head, and their livers excised without rupturing the gall bladder, wrapped in aluminium foil and frozen in liquid nitrogen.

For assay, livers were allowed to thaw slowly on ice to minimise membrane disruptive effects and their wet weights recorded. Approximately $0.5 \mathrm{~g}$ samples were dried at $100^{\circ} \mathrm{C}$ for $24 \mathrm{~h}$ to obtain dry weights prior to metal analysis. For fractionation, 0.5 to $0.6 \mathrm{~g}$ samples were homogenised for $30 \mathrm{~s}$ in $2 \mathrm{ml}$ ice-cold buffer containing $50 \mathrm{mM}$ potassium phosphate, $0.25 \mathrm{M}$ sucrose, $1 \% \mathrm{w} / \mathrm{v} \mathrm{KCl}$, and $15 \%$ v/v glycerol, $\mathrm{pH} 7.6$ using a Polytron ${ }^{\mathrm{TM}}$ rotating blade homogeniser (Janke \& Kunkel AG, Luzern) operating at half speed. After addition of homogenisation medium used for rinsing the homogeniser probe, the homogenate was made up to $3 \mathrm{ml}$, divided into 2 aliquots between $2.5 \mathrm{ml}$ microcentrifuge tubes and centrifuged at $10000 \mathrm{rpm}$ $(8000 \times g)$ for $10 \mathrm{~min}$ at $4{ }^{\circ} \mathrm{C}$ to prepare a postmitochondrial supernatant. The supernatants were removed by syringe and EROD assays were performed immediately. Metallothionein assays were performed after storage for up to $2 \mathrm{~d}$ at $-80^{\circ} \mathrm{C}$.

Assays were performed as described previously (George \& Young 1986). Cytochrome P-450 dependent 7-ethoxyresorufin $\mathrm{O}$-deethylase (EROD) activity was determined fluorimetrically by determination of resorufin production using an Aminco Bowman model SP125 spectrophotofluorimeter, spiked addition of resorufin to the reaction mixture being used as calibration. Metallothionein (MT) was determined after heat treatment of the post mitochondrial supernatant for $4 \mathrm{~min}$ at $95{ }^{\circ} \mathrm{C}$ by ${ }^{109} \mathrm{Cd}$ saturation assay. Proteins were determined by the Lowry procedure after solubilisation in
$0.3 \%$ sodium dodecyl sulphate and dilution to $0.1 \%$ SDS using bovine serum albumin as standard. For metal analysis, dried tissue samples were wet ashed in $\mathrm{cHNO}_{3}$ using Teflon pressure vessels and metal concentrations were determined with a Varian Techtron Model 555 atomic absorption spectrophotometer, again as described previously (George \& Young 1986).

Condition factors $(\mathrm{K})$ were calculated using the equation $\mathrm{K}=\mathrm{W} / \mathrm{L}^{3}$, where $\mathrm{W}=$ wet weight $(\mathrm{g})$ and $\mathrm{L}=$ length (mm). Liver somatic index (lsi) is the liver weight expressed as a percentage of the total body weight. Results are tabulated as means $\pm \mathrm{SE}$, however, many parameters showed non-normal distributions and are therefore plotted as box-and-whisker plots showing the medians, 10th and 90th percentiles. Normalisation of the data could not be acheived by simple transformations and therefore a parametric analysis of variance (1way ANOVA) was utilised for statistical analysis; significance was established at $\mathrm{p}<0.05$ and $\mathrm{p}<0.01$.

\section{RESULTS}

\section{Reference areas}

Fish collected from the Firth of Clyde and the Ythan estuary did not display significant differences in any of the parameters measured and therefore have been treated as a single reference group. Condition factors and lsi's (Table 1) did not indicate any abnormalities or ill health; EROD activities and metallothionein concentrations were low, indicative of a lack of pollutant contamination at these sites. These sites may therefore be regarded as clean reference sites.

\section{River Forth and estuary}

The condition indices, lsi's, hepatic protein concentrations, EROD activities and MT levels in fish sampled from the Forth are given as mean values \pm SEM in Table 1; the median and percentiles for the EROD and MT data are plotted in Fig. 1, which also shows the sampling stations. We have found no correlation $(p>0.05)$ between body size and any of the above parameters in a large sample of flounders (98) varying from 27 to $580 \mathrm{~g}$ wet wt (unpubl.). The present study utilised sexually immature fish ranging from 37 to $240 \mathrm{~g}$ which for this population are from 1 to $3 \mathrm{yr}$ old.

Condition factors decreased progressively down the river and estuary with Cornton $>$ Alloa, Kincardine $>$ Longannet, Port Edgar. Those of the Alloa and Kincardine fish were the same as the reference fish. Whilst the lsi of the Cornton fish was the same as the reference fish, the livers of fish from other sites along the Forth 


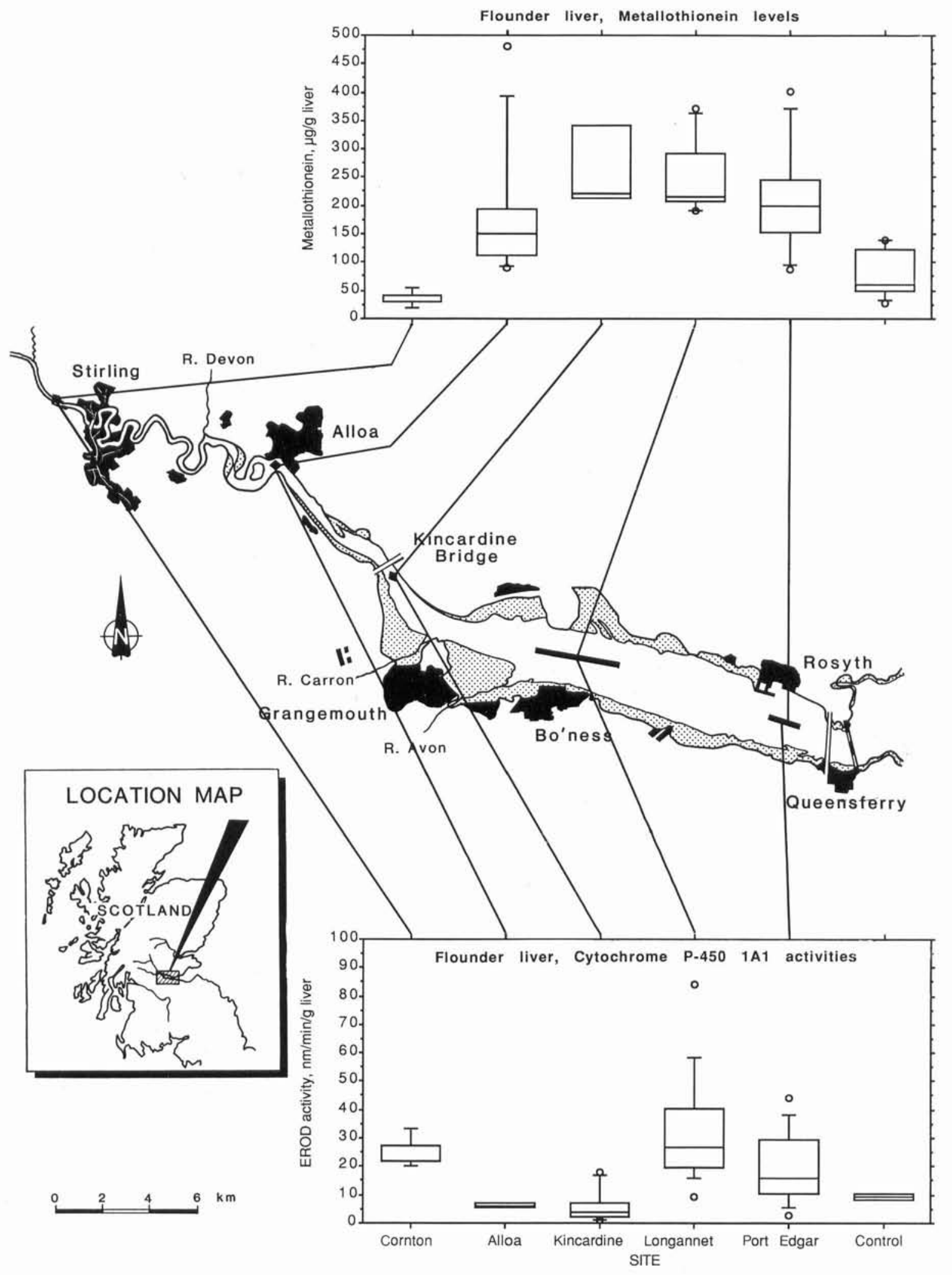

Fig. 1. Platichthys flesus. Hepatic metallothionein concentrations and ethoxyresorufin O-deethylase (Cytochrome P-450 1A1) activities in fish from different sampling stations along the Forth estuary, Scotland. Boxes: 1st and 3rd quartiles either side of the medians, lines: 10 th and 90 th percentiles with outlier points plotted 
Table 1. Platichthys flesus. Condition factor (K), liver somatic index (lsi, \%), liver EROD activity $\left(\mathrm{nmol} \mathrm{g} \mathrm{liver}^{-1} \mathrm{~min}^{-1}\right)$ and liver MT concentrations $\left(\mu \mathrm{g} \mathrm{g}^{-1}\right)$ in flounders from reference and Forth estuary sites. Means \pm SE with numbers of fish analysed in parentheses. For sites, significant differences from the references sites (Clyde and Ythan) indicated by ${ }^{*} \mathrm{p}<0.05,{ }^{\cdots} \mathrm{p}<0.01$

\begin{tabular}{|c|c|c|c|c|c|c|}
\hline Site & Condition & lsi & EROD & & MT & \\
\hline \multicolumn{7}{|l|}{ Reference } \\
\hline Clyde, Ythan & $1.48 \pm 0.12$ & $1.19 \pm 0.12$ & $9.2 \pm 0.9$ & (4) & $79 \pm 17$ & (7) \\
\hline \multicolumn{7}{|l|}{ Forth } \\
\hline Cornton & $1.77 \pm 0.06^{\circ}$ & $1.24 \pm 0.07^{\circ}$ & $24.5 \pm 2.4^{\cdots}$ & (5) & $34 \pm 6$ & (5) \\
\hline Alloa & $1.46 \pm 0.01$ & $1.67 \pm 0.21^{\circ}$ & $5.8 \pm 0.8^{\circ}$ & (5) & $142 \pm 18$ & (7) \\
\hline Kincardine & $1.48 \pm 0.01$ & $1.97 \pm 0.06^{\cdots}$ & $5.8 \pm 2.6$ & (6) & $270 \pm 57^{\cdots}$ & (3) \\
\hline Longannet & $1.1 \pm 0.07^{*}$ & $1.67 \pm 0.06^{\circ}$ & $32.6 \pm 5.3^{*}$ & (14) & $248 \pm 28^{\cdots}$ & (6) \\
\hline Port Edgar & $1.18 \pm 0.13^{\circ}$ & $1.75 \pm 0.11 \cdots$ & $19.8 \pm 4.1$ & (10) & $215 \pm 38^{\cdots}$ & (8) \\
\hline
\end{tabular}

were significantly enlarged $(p<0.05)$. Whilst the decrease in condition factors and liver enlargement appeared to show some correlation with pollutant impacts there was no direct relationship with size or a single biochemical parameter and these could therefore also be related to some other physiological parameter such as salinity.

Hepatic cytochrome P-450 dependent EROD activity differed between sites. Fish from Cornton, Longannet and Port Edgar showed significantly higher activities than the Alloa and Kincardine fish ( $p<0.01)$. Compared with the reference fish, which had an activity of 9 nmol $\min ^{-1} \mathrm{~g}^{-1}$, the activities in fish from Kincardine and Alloa were slightly lower although only the group from Alloa showed a statistically significant difference $(\mathrm{p}<0.05)$; fish from Cornton showed a 2.5 -fold elevation in activity $(\mathrm{p}<0.01)$ whilst fish from Longannet showed a 3.5 -fold elevation $(\mathrm{p}<0.05)$ with activities in individual fish as much as 9-fold greater. Although some individuals from Port Edgar were raised 4-fold, there was a large variation between individuals and thus the elevation in the median value of 2 -fold respectively was not statistically significant.

Hepatic MT levels showed highly significant variations with sites (Table 1, Fig. 1); levels in Cornton fish $\left(34 \pm 6 \mu \mathrm{g} \mathrm{g}^{-1}\right)$ were very low and approximately half those in fish from the reference area. Levels in fish from all other stations on the Forth were some 4- to 7-fold higher than in those from Cornton. Whilst there appeared to be a maximum at Kincardine, again there was a wide variation in MT levels between fish from all the stations in the lower estuary (from 87 to $400 \mu \mathrm{g} \mathrm{g}^{-1}$ ) and therefore no statistically significant difference between these sites was observed. Metal analyses of livers of the Forth flounders (Table 2) showed that compared with Cornton fish the concentrations of $\mathrm{Cu}$ were approximately 2-fold higher in fish from Port Edgar, 3-fold higher in fish from Alloa and Kincardine and 6-fold higher in those from Longannet. Whilst there also appeared to be a peak in hepatic $\mathrm{Zn}$ and $\mathrm{Pb}$ concentrations in Longannet fish there were no statistically significant differences in their concentrations between sites.

\section{DISCUSSION}

EROD activities in Flounders from the references sites were some 3 - to 4 -fold higher than those reported for fish from the references site (Solbergstand) in the GEEP workshop (Addison \& Edwards 1988, Stegeman et al. 1988). This is not attributable to seasonal variations and whilst it is unlikely that it can be explained by interlaboratory differences in measurement, it may indicate that the reference sites in the present study were not entirely free of hydrocarbon contamination. Indeed in the present study the lowest values were obtained in fish sampled from stations on the Forth rather than from the reference sites. Hepatic

Table 2. Platichthys flesus. Concentrations of metals ( $\mu \mathrm{g} \mathrm{g}^{-1}$ dry wt) in the liver of flounders from 5 sites along the Forth. Means $\pm \mathrm{SE}$ with numbers of fish analysed in parentheses. For sites, significant differences from Cornton indicated by ${ }^{*} \mathrm{p}<0.05$, $\because \mathrm{p}<0.01$

\begin{tabular}{llrrrrr}
\hline Site & Copper & Cadmium & Zinc & Lead \\
\hline Cornton & $10 \pm 1$ & $(3)$ & - & $75 \pm 2(3)$ & $2.4 \pm 0.8(3)$ \\
Alloa & $34 \pm 7^{\circ}(6)$ & $0.6 \pm 0.1(6)$ & $73 \pm 6(6)$ & $2.3 \pm 1.1(6)$ \\
Kincardine & $31 \pm 5^{\circ}(9)$ & $0.9 \pm 0.4(6)$ & $90 \pm 13(9)$ & $0.8 \pm 0.2(4)$ \\
Longannet & $63 \pm 8^{*}(7)$ & $0.6 \pm 0.3(5)$ & $113 \pm 22(10)$ & $4.7 \pm 0.5(3)$ \\
Port Edgar & $23 \pm 8$ & $(3)$ & $0.8 \pm 0.1(3)$ & $64 \pm 15(6)$ & $1.5 \pm 0.7(3)$ \\
\hline
\end{tabular}


metallothionein levels in the reference fish from the Clyde and Ythan estuaries were quite low and approximately half those of reference site in the Norwegian GEEP study from Solbergstrand (Overnell \& Abdullah 1988 ) indicating that these Scottish estuaries were free from metal contamination.

The Forth estuary has had a long history of discharges of industrial and domestic waste and Scotlands's major petrochemical industry and refinery has been located at Grangemouth since 1924. Whilst discharges have been reduced dramatically over the past decade, estimated industrial inputs are still significant; estimated values for hydrocarbon input in 1986 was estimated at $3400 \mathrm{~kg} \mathrm{~d}^{-1}$ (Elliot \& Griffiths 1987) and for toxic metal inputs in 1984 were Cd $5.1 \mathrm{~kg} \mathrm{~d}^{-1}, \mathrm{Cr} 2.7 \mathrm{~kg}$ $\mathrm{d}^{-1}$ and $\mathrm{Hg} 3.4 \mathrm{~kg} \mathrm{~d}^{-1}$ (Davies 1987). Although there have been localised lethal effects on biota, particularly on the intertidal mudflats around the discharges, there have been no widespread deleterious effects (McLusky 1987). However, due to the physical and hydrographic characteristics of the estuary a large reservoir of metal and hydrocarbon contaminants is present in the sediments (Davies 1987, Elliot \& Griffiths 1987). Data for hydrocarbon and PCB concentrations in flounder at sites along the Forth are lacking; however, present EROD results clearly show evidence for a graded response of flounders to organic pollutants along the the estuary. The highest EROD values were observed in fish caught nearest the petrochemical production/ refinery complex. The high values in fish obtained above Stirling are not so readily explicable; whilst there is a domestic sewage treatment plant serving ca 10000 people $6 \mathrm{~km}$ upstream, this area is largely agricultural and the only known hydrocarbon input is run off from ca $13 \mathrm{~km}$ of motorway and $8 \mathrm{~km}^{2}$ of conurbation.

The extremely low MT values for the uppermost sampling station at Cornton show the lack of metal pollutant impact at this site; downstream there was very clear induction of hepatic MT levels. There was no statistically significant difference in hepatic metallothionein levels between fish caught from Kincardine, Longannet or Port Edgar which were some 6- to 9-fold higher than the Cornton fish. The highest concentrations of $\mathrm{Cu}, \mathrm{Zn}$ and $\mathrm{Cd}$ were all found in flounders from Kincardine indicating that bioavailability of these metals was greatest at this site. Metal analyses of sediments in the Forth show that whilst the total concentrations of $\mathrm{Cd}, \mathrm{Cu}$ and $\mathrm{Hg}$ appear to be highest around Kincardine, the distribution of 'hot spots' within the estuary is extremely patchy (Davies 1987, Forth River Purification Board annual reports; unpubl. results of this laboratory) and the concentrations in the $0.1 \mathrm{~N}$ $\mathrm{HCl}$ extractable fraction of the superficial sediments do not follow the total metal concentrations. Thus it is unlikely that determination of sedimentary metal concentrations will reflect bioavailability. Whilst polychaete worms such as Nereis spp. can provide useful information on the bioavailability of metals from sediments (Bryan et al. 1985), again the information is highly site-specific. Use of flounders as an indicator of bioavailability of metals has the advantages that they are not highly site specific and that they will provide an integration of metal levels in animals at lower trophic levels; moreover, they also have a wide geographic range since they display a wide salinity tolerance. The present study contrasts with that of Overnell \& Abdullah (1988) who found little very little change in MT levels in flounder collected along a pollution gradient in the Langesundfjord in Norway or in fish exposed to waterborne $\mathrm{Cu}$ in mesocosms. The lack of response in this previous study presumably reflects a lack of metal bioavailability in the Norwegian study.

Olson et al. (1978) demonstrated that whilst inorganic $\mathrm{Hg}$ was bound to MT and induced its syntheses in trout, methyl mercury did not bind to the protein and did not induce its synthesis. Although $\mathrm{Hg}$ pollution in the Forth is considerable, analyses have shown that this is almost entirely methylated both within the estuary and in flounders (Davies 1987). Therefore it is unlikely that the elevated MT levels are attributable to $\mathrm{Hg}$ pollution. From the present work it cannot be determined whether MT induction can be attributed to one or all 3 of the inducing metal triad, $\mathrm{Cu}, \mathrm{Cd}$ or $\mathrm{Zn}$.

From this study we conclude that measurement of flounder hepatic EROD activity and metallothionein content has provided a sensitive indication of the expected pollution gradient in the Forth estuary and should prove a useful method for assessment of biological impact of the discharges in this estuary, and other marine and estuarine sites.

Acknowledgements. We thank all those who helped us obtain fish, the skippers of the Stake boats, Mr D. Fawcett and Mr W. McBrien and the crew of the 'Forth Ranger' (FRPB).

\section{LITERATURE CITED}

Addison, R. F., Edwards, A. J. (1988). Hepatic microsomal mono-oxygenase activity in flounder Platichthys flesus from polluted sites in Langesundfjord and from mesocosms experimentally dosed with diesel oil and copper. Mar. Ecol. Prog. Ser. 46: 51-54

Bayne, B. L., Clarke, K. R., Gray, J. S. (eds.) (1988). Biological effects of pollutants. Results of a practical workshop. Mar. Ecol. Prog. Ser. 46: 1-278

Boobis, A., Caldwell, J., DeMatteis, F., Davies, D. (eds.) (1985). Microsomes and drug oxidations. Taylor Francis Ltd., London

Bryan, G., Langston, W. J., Hummerstone, L. G., Burt, G. R. (1985). A guide to the assessment of heavy metal contamination in estuaries using biological indicators. Mar. biol. Ass. U.K. Occ. Publ. No. 4 
Davies, I. M. (1987). Trace metals and organohalogen compounds in the Forth, Scotland. Proc. R. Soc. Edinb. 93B: 315-326

Elliot, M., Griffiths, A. H. (1987). Contamination and effects of hydrocarbons on the Forth ecosystem, Scotland. Proc. R. Soc. Edinb. 93B: 327-342

George, S. G. (1990). Biochemical and cytological assessments of metal toxicity in marine animals. In: Furness, W. R., Rainbow, P. S. (eds.) Heavy metals in the marine environment. CRC Press, Boca Raton, p. 123-142

George, S. G., Young, P. (1986). The time course and effects of cadmium and 3-methylcholanthrene on activities of enzymes of xenobiotic metabolism and metallothionein levels in the plaice, Pleuronectes platessa. Comp. Biochem. Physiol. 83C: 37-44

GESAMP (1980). Monitoring biological variables related to marine pollution. Reports and studies, No. 12, UNESCO, Paris

Kagi, L. H. R., Kojima, Y. (eds.) (1987). Metallothionein II. Experientia Suppl. 52

Kleinow, K., Melancon, M., Lech, J. J. (1987). Biotransformation and induction: implications for toxicity, bioaccumulation and monitoring of environmental xenobiotics in fish. Environ. Health Perspect. 71: 105-119

Hamer, D. (1987). Metallothionein. Ann. Rev. Biochem. 55: 913-951

Hamilton, S. J., Mehrle, P. M. (1986). Metallothionein in fish:

This article was presented by Dr D. S. McLusky, Stirling, Scotland review of its importance in assessing stress from metal contaminants. Trans. Am. Fish. Soc. 115: 596-609

Heilmann, L. J., Sheen, Y.-Y., Bigelow, S. W., Nebert, D. W. (1988). Trout P4501A1: cDNA and deduced protein sequence, expression in liver and evolutionary significance. DNA $7: 379-387$

McLusky, D. S. (1987). Symposium. The natural environment of the estuary and Firth of Forth. Proc. Soc. Edinb. 93B: 235-571

Overnell, J., Abdullah, M. I. (1988). Metallothionein and metal levels in flounder Platichthys flesus from four field sites and in flounders dosed with water-borne copper. Mar. Ecol. Prog. Ser. 46: 71-74

Payne, J. F., Fancey, L. L., Rahimtula, A. D., Porter, E. L. (1987). Review and perspective on the use of mixed function oxygenase enzymes in biological monitoring. Comp. Biochem. Physiol. 86C: 233-245

Olson, K.R., Squibb, K., Cousins, R. J. (1978). Tissue uptake, subcellular distribution and metabolism of ${ }^{14} \mathrm{CH}_{3} \mathrm{HgCl}$ and $\mathrm{CH}_{3}{ }^{203} \mathrm{HgCl}$ by rainbow trout, Salmo gairdneri. J. Fish. Res. Bd Can: 35: 381-390

Stegeman, J. J., Kloepper-Sams, P. J. (1987). Cytochrome P450 isoenzymes and monooxygenase activity in aquatic animals. Environ. Health Perspect. 71: 87-95

Stegeman, J. J., Woodin, B. R., Goksoyr, A. (1988). Apparent cytochrome P-450 induction as an indication of exposure to environmental chemicals in the flounder Platichthys flesus. Mar. Ecol. Prog. Ser. 46: 55-60

Manuscript first received: May 24, 1990

Revised version accepted: August 30, 1990 